F. P. Clausen

professor, cand.mag.

logle synspunkter på historien

De efterfolgende sider gengiver et foredrag, holdt ved et mode af nordiske videnskabshistorikere pa Aarhus Universitet $i$ eftersommeren 1967. Titlen var dengang: "Moderne synspunkter på historien." Teksten er altså fire år gammel og præget deraf, men den gengives allige:el i den form, foredraget havde, da det blev holdt. Kun cnkelte, helt formelle andringer er foretaget.

Det har naturligvis sine ulemper at bringe teksten uden hensyn til den debat, der siden har fundet sted. På den anden side giver det en mulighed for at sætte den optimisme m.h.t. en integration af historien med samfundsvidenskaberne, som præger foredraget, $i$ relief, ved at den konfronteres med udviklingen siden 1967.

Man må da nok erkende, at der $i$ hvert fald $i$ den hjemlige sammenhæng ikke er sket meget $i$ den retning, der $i$ foredraget betragtes som onskvardig. Den historieforskning, der er produceret $i$ de sidste år, har ikke været præget af, at forskerne har orienteret sig mod samfunds videnskabelige problemstillinger, heller ikke hvor emnerne skulle synes at indbyde til det.

$P \&$ den anden side kan der findes adskillige tegn p\&, at historikere andre steder har taget udfordringen op. Det gælder f.eks. i Norge, hvor man arbejder intensivt med undersogelser af partier og grupper i Stortinget $i$ perioden 1857-1940 under anvendelse af maskinel databehandling af afstemninger ved navneopråb. Også en stort anlagt undersøgelse af vælgeradfærden $i$ Kristiania $\$ 1800-$ tallet vil snart se dagens lys $i$ oslo, og den henter tydeligt i sit oplæg og sin metodik inspiration fra politologiens og andre samfundsvidenskabers arbejde med beslægtede problemer. En svensk historiker, der nu virker i Norge arbejder desuden med moderne politologiske kategorier i forbindelse med antik historie. 
Dette er tilfældige eksempler, som er kommet indenfor min synskreds. De viser dog, at der er historikere, som virkelig orienterer sig $i$ de retninger der er antydet $i$ foredraget. At dette var programmatisk tænkt, mere end det var udtryk for en beskrivelse af de forhåndenvarende, faktiske muligheder, ma vel tilfojes for at understrege den beskedne rækkevidde $i$ de anforte synspunkter.

Imidlertid bor det nok tilfojes, at man netop nu bl.a. i politologien kan registrere en aftagende interesse for debatten om disciplinens definition og afgrænsning mod andre discipliner. Det problem optog for fa ar siden sindene langt mere, end det gor $\mathbf{i}$ dag, hvor man indtager en forholdsvis afslappet holdning til sagen. Heri kan vel ogsa ligge en antydning af, at nogle af de problemer, der har kunnet danne en barriere for en integrationstendens langsomt demonteres. Det afgorende er jo for sa vidt, at en aben holdning etableres disciplinerne imellem.

Endelig má det tilfajes, at de sidste par ars debat omkring værdiproblemerne $i$ videnskaben til en vis grad har bremset udviklingen i retning af integration, fordi sá meget $i$ samfundsvidenskaberne, navnlig de kvantificerende tendenser, er blevet angrebet. Men samtidig har hele denne debat måske alligevel på lidt langere sigt bidraget til at oge fornemmelsen af sammenhæng mellem disciplinerne.

Det har forbindelse med, at man har genopdaget vigtige sider af det gamle problem om de særlige vilkar, der hersker ved studiet af menneskets aktivitet i samfundet. De alt for enkle kausalforklaringer i samfundsvidenskaberne er bragt $i$ miskredit, og det har fort til en erkendelse af, at den historiske, individualiserende betragtning ogsa - $i$ en anden formulering end den klassiske har relevans for en samfundsvidenskabelig betragtning.

Læser man f.eks. Gerard Radnitzkys store og desværre alt for svært tilgængelige værk, Contemporary Schools of Metascience, Göteborg 1570, vil man fa et indtryk af, at ogsa ud fra en hermeneutisk synsvinkel, tegner der sig pa det teoretiske plan muligheder for en in- 
tegration af de forskellige metodiske approaches i samfundsvidenskaberne. Den alt for forenklede modstilling af en sakaldt positivisme med en sakaldt hermeneutisk skole kan meget let vise sig i den praktiske forskning - og den er dog ikke ganske uden interesse - at forvandle sig til en udvikling i retning af en integreret, mere nuanceret og humant orienteret samfundsvidenskab.

Skulle de følgende betragtninger have været skrevet nu, måtte de have taget deres udgangspunkt $i$ den her kort skitserede situation. Forhabentlig vil det dog ikke være helt uden interesse umiddelbart for de sidste års vigtige diskussion for alvor satte ind.

\section{Baggrunden for synspunkterne}

Det er helt klart, at jeg i det folgende kun kan tage et lille og tilfældigt udvalg frem af de sporgsmal, der diskuteres af nutidens historikere. Og det vil da blive de problemer, som af forskellige grunde optager mig selv - med fare for, at de dels ikke er repræsentative for debatten som helhed, dels ikke interesserer historikere, der befinder sig i helt andre situationer.

Den moderne historieforskning er så omfattende og så specialiseret på enkelt-discipliner, at det er ganske uansvarligt at tale om "historien", som om historieforsk. ningen var en ukompliceret enhed, som en enkelt mand kan tillade sig at have synspunkter på. Hvad der forekommer en politisk historiker væsentligt og vedkommende vil muligvis være totalt uden interesse for en videnskabshistoriker. En religionshistorikers problemer har formentlig meget lidt at sige den, der er optaget af at granske toldregnskaber for at skrive salthandelens historie.

Hvad jeg da må nøjes med er at fremlægge nogle overvejelser, der dukker op pá den horisont i historieforskningen, der er blevet min. For at De straks kan fá et indtryk af, hvad De kan vente $i$ det folgende, vil jeg begynde med at beskrive baggrunden for mine synspunkter.

De vil være farvet af, at jeg er historiker med 
hovedinteressen rettet mod de sidste to arhundreders historie, og af, at jeg ikke har mit daglige arbejde $i$ et $i$ egentlig forstand historisk milieu. Jeg er ansat ved Institut for Statskundskab, og som jeg opfatter det, er meningen med mit arbejde dêr at skabe samarbejde og sammenhæng mellem historien og de andre videnskabelige discipliner, der er samlet under betegnelsen den politiske videnskab eller statskundskab.

Institut for Statskundskab i Arhus omfatter bl.a. en sociologisk og en afdeling for politiske sagomrader, hvis arbejdsomrade vel er det, der ligger nærmest ved historien. Ved et samarbejde mellem disse to afdelinger gennemfores blandt andre ting et kursus $i$ samfundsvidenskabelig forskningsteknik, og dette kursus er obligatorisk for alle statskundskabs - og samfundsfagsstuderende. I det gives lige dele historisk og sociologisk forskningsteknik.

Jeg nævier ikke dette som en tilfældighed. I virkeligheden karakteriserer det selve grundlaget for det, jeg vil sige $i$ dag. $V i$ forsoger ved vort institut $i$ et vist omfang at integrere historien og de andre samfundsvidenskabelige discipliner, der er samlet omkring studiet af statskundskab. Forst og fremmest prover $i$ at etablere det snævrest mulige samarbejde mellem historie pa den ene side og fag som sociologi og international politik pa den anden.

Det betyder naturligvis, at min interesse både teoretisk og mere praktisk vil være rettet mod det, der forbinder historien med dens systematiserende nabodiscipliner. Men for at give historien den rette vægt og placering $i$ samarbejdet mellem samfundsvidenskaberne, må man naturligvis ogsa prove at analysere de trak ved den historiske forskning, som giver den en særstilling blandt samfundsdisciplinerne og adskiller den fra naboerne - sociologi, antropologi, socialpsykologi, nationaløkonomi, etnologi, og hvad der ellers kan være tale om.

Dermed har jeg mere end antydet mine a prioriske forudsætninger, som naturligvis vil give mine betragtninger en skavhed. Men jeg tror egentiig ikke, det beho- 
ver at være en skæuhed $i$ dårlig betydning af ordet. Det er mere en hældning mod en række af de problemer, som optager $i$ hvert fald en del moderne historieforskere.

Bl.a. vil det bevidste arbejde med at bringe historien på plads $i$ en samfundsvidenskabelig sammenhæng ikke kunne gores, uden at man dyrker historiens metodiske problemer ganske grundigt. $0 \mathrm{~g}$ dermed er vi givetvis fremme ved et af den moderne historieforsknings helt karakteristiske kendetegn: En stærkt voksende interesse for historiens teoretiske og metodiske problemer.

\section{Voksende metodeinteresse}

Den svenske historiker, docent Rolf Torstendahl, har i sin bog om "Historia som vetenskap" gjort opmærksom på, at interessen for den historiske forsknings teori fordeler sig meget ujæunt i historieskrivningens historie. De vigtigere behandinger af historieskrivningens problemer falder ligesom i grupper, samlet om bestemte tidspunkter med betydelig afstand imellem.

0mkring århundredskiftet ligger en sådan interessetop med de stort anlagte håndboger af Bernheim og Langlois/Seignobos. I Norden kan bl.a. svenskeren Harald Hjärne og danskeren Kr. Erslev placeres $i$ dette konjunkturudsving $i$ den historiske metodeinteresse.

og netop nu befinder vi os uden for al tvivi midt $i$ en ny bolge af historieteori, der ogsa har nåt de skandinaviske lande. Jeg kan som et par af de ydre tegn på denne fornyede metodeinteresse næune, at $i 1960$ begyndte man udgivelsen af et internationalt tidsskrift for historieteori og historiefilosofi med titlen History and Theory. og siden 1965 har nordiske historikere holdt arlige seminarer til droftelse af metodiske problemer.

Det er fristende at sporge efter åsagerne til, at metodediskussionen oplever denne blomstring. Et svar på sporgsmålet må nødvendigvis blive upræcist og til dels personligt præget, men jeg tror, det kan være ganske nyttigt at prove at formulere et svar alligevel. 
Pa sin vis kan man godt trække et par grove paralleller mellem den ojeblikkelige hojkonjunktur for historieteori og den foregående omkring 1900. Dengang søgte man efter den stærke udvikling, historieforskningen havde gennemlobet $i$ det 19. arhundrede - at finde frem.til formler for historieforskningens videnskabelige karakter. De to beromte franskmand, Langlois og Seignobos, ville med deres store "Introduction aux études historiques" fra 1898 ud fra en positivistisk præget erkendelsesteori give historien et videnskabeligt fundament. Samtidig sogte andre, navnlig tyske historikere og filosoffer, $i$ et opgor med positivismens videnskabsbegreb at argumentere for, at historien var en disciplin med sine egne normer og standarder, forskellige fra dem, der var gældende $i$ andre videnskaber. Samtidig med denne metodedroftelse, der fandt sted $i$ tilslutning til eller $i$ skarp opposition til positivismen, udspilledes et ganske dramatisk opgor mellem på den ene side de historikere, der hævdede den traditionelle, politiske histories primat i,forskningen, og på den anden side de historikere, der onskede at udvide synsfeltet til en alt omfattende kulturhistorie. Denne kulturhistoriske orientering, der som bekendt havde sin stærkeste fortaler i tyskeren Lamprecht, kom til at sætte sine kraftigste spor i USA. Fra o. 1910 talte man i Amerika ligefrem om en New History, der var karakteriseret ved at være orienteret mod en bred udforskning af det menneskelige samfund $i$ fortiden med en forskydning af vægten fra det politiske mod det okonomiske og sociale. Denne udvikling lob parallelt med en vækst $i$ samfundsvidenskaberne.

Noget senere satte en lignende udvikling ind $\mathbf{i}$ Frankrig, ledet af fremtrædende historikere som Marc Bloch, Lucien Febvre og Ferdinand Braudell. Men centrum i tidsskriftet Annales d'histoire économique et sociale (fra 1929) udfoldede sig en frugtbar forskning, der bevidst vendte sig bort fra "begivenhedshistorien" eller "overfladehistorien", som den blev kaldt, till et studium af de dybere liggende, mere varige og omfattende bevægelser 
i samfundenes udvikling.

\section{Historiens krise}

Jeg skal senere vende tilbage til denne retning i fransk historieforskning. Men forst vil jeg tage tráden op igen ved den metodiske debat ved dette a rhundredes begyndelse. Man kan på en måde sige, at hele metodediskussionen og den baggrund, hvorpa den fortes, var udtryk for en slags krise $i$ historieskrivningen. Med udtrykket krise mener jeg her ikke nødvendigvis noget negativt. Jeg mener en spændingsfyldt, forvirret og sammensat situation, der $\$$ høj grad viste sig ogsa at have frugtbare muligheder i sig.

Positivismen brodes med et kraftigt kritisk modstod; politiske historikere sloges med kulturhistorikere om fagets afgrænsning; systematiske samfundsvidenskaber voksede op ved siden af historien og gav sig $i$ lag med emneomrader, som historikerne hidtil havde været ene om. Alt dette er træk $i$ krisesituationen.

Vender vi os nu mod øjeblikkets metodeinteresse, kan man ogsa der argumentere for den påstand, at metodedebatten foregår i en situation med krisetræk for historieforskningen. Nogle af elementerne $i$ den nuværende situation er iovrigt en arv fra den spandingsfyldte, intellektuelle atmosfære omkring historien ved århundredskiftet.

Helt eksplicit blev den nye krisefornemmelse udtrykt i tre særdeles interessante særnumre, som Times Litterary Supplement udgav sidste ar (1966). De behandlede historiens problemer og havde fået titlen New Ways in History.

I det forste af numrene karakteriserede oxfordhistorikeren Keith Thomas det 20. arhundrede som en tid, da de fleste historikere midlertidigt mistede orienteringen. I en ledende artikel uddybedes denne pastand med en betragtning om, at på trods af eller måske netop fordi historien har nået en særdeles hoj professionel status, er den $i$ dag grebet af en gennemtrængende folelse af ubehag eller sygdom. Og kommentatoren citerer en yngre engelsk 
historiker, der i en tiltrædelsesforelæsning skal have sagt, at tvivl og utilfredshed med faget aldrig har været tydeligere end $i$ disse år med fagets hurtige vækst.

\section{Konsekvensen af samfundsudviklingen}

Nu foler naturligvis ikke alle historikere pa denne måde, men når nogle gor, skyldes det en række ting, som tilsammen skaber en særdeles spændingsfyldt situation. I det ydre kan man pege på de enorme endringer $i$ vore samfund, som vi alle har oplevet og lever med i. Udvidelsen af den politiske horisont efter 2. verdenskrig, Asiens og Afrikas opdeling i selvstandige stater med indflydelse pa storpolitikken, fremvæksten af de to supermagter $i$ ost og vest som en understregning af, at $i$ den moderne verden hænger alle problemer sammen, så de ikke mere kan betragtes blot inden for en snæver nationalstatslig ramme; $u$ lands-problemet med dets okonomiske og politiske konsekvenser også for de udviklede lande; den tekniske udvikling med de ogede kommunikationsmuligheder - alt dette og mere til har sprærigt den harmoni og de snævre rammer, hvori historien kunne dyrkes endnu i mellemkrigstiden.

og helt tæt ind på livet har historikerne i sa at sige alle lande et samfund $i$ rivende okonomisk vakst og udvikling. Endringerne $i$ vore egne skandinaviske lande blot $i$ de sidste 10 år har jo været voldsommere og mere dybtgående, end $v i$ har kendt dem på noget tidligere tidspunkt. Hvis man et ojeblik tor bruge den grove pensel, kan man godt sige, at der er sket mere $i$ en række heiseender $\mathbf{i}$ de sidste $25 \mathrm{ar}$, end der skete $i$ hele det 19. arhundrede.

I hvert tilfælde er der ingen, der nu til dags kan fole sig $i$ tvivl om, at han lever $i$ et samfund $i$ stærk bevægelse. Sansen for, at tingene er underkastet forvandlingens lov med stigende hastighed, og at de politiske ræssonnementer tilsyneladende har suært ved at folge trop med okonomiske og andre ændringer $i$ samfundet, skærpes $i$ disse ar. Det har faet folger for historikernes holdning 
til deres disciplin.

Det er ikke mere sa let at skrive historie ud fra det bestående og vel etablerede samfunds synsvinkel. På den made er ellers megen historie - og megen god historie må man tilføje - hidtil belvet skrevet. Tænk blot på, hvordan selv meget radikale historikere i de skandinaviske lande helt til det sidste har været optaget af at skildre vor historie som optakten til og forudsatningen for den bedste af alle verdener; den vi fandt frem til gennem en politisk og social frigorelsesproces, der forte til den nordiske velfærdsstat og det nordiske folkestyre. Når det er nåt, formodes verden vistnok at sta stille. Historien er skrevet fra det etablerede samfunds synspunkt.

Bevægeligheden og de hurtige skift $i$ de seneste års udvikling gor det svart stadig at indtage en sådan entydig position og tro på de lige forlob i historien. Principielt er der vel to mulige måder, hvorpa historikerne kan reagere pa tidens udfordring. De kan indtage det synspunkt, at jo mere samfundet er $i$ bevægelse eller ligefrem i skred, des vigtigere bliyer det at besinde sig på historien, som $v i$ kender den. $V i$ må fastholde perspektivet bagud, så vi ikke under indtryk af den nye tid mister fodfæstet og sansen for traditionen. Denne holdning er formuleret af mange historikere $i$ de seneste ar.

Kontinuitet og diskontinuitet

Men den sidste generations erfaringer kan tilsyneladende ogsa omsættes til en trang til at beskrive og forsta selve forudsætningerne for de vældige omvæltninger, $v i$ just nu oplever. Det foles nodvendigt at søge sammenhæng $i$ det, vi oplever, ikke mindst fordi sammenhængen og den gensidige afhængighed mellem de enkelte elementer $i$ udviklingen fornemmes starkere end nogensinde. Det er naturligvis lidt af en tom frase at sige, at alt i den moderne verden hænger sammen.

Men slagordet dækker jo dog over noget, vi føler som en realitet, og det sætter sine spor $i$ mange histori- 
keres overvejelser. De storre sammenhænge, den indbyrdes samfundsmæsige afhængighed mellem politiske, okonomiske, kulturelle og sociale faktorer er iojnefladende $i$ det samfund, vi lever $i$.

Det har været almindeligt at hæude, at den brede, samfundsorienterede New History, jeg for talte om, havde ganske særlige muligheder for at udvikle sig i USA, fordi man der havde et samfund i hurtig udvikling. Det var let umiddelbart at få oje på, at okonomi, politik og social udvikling $i$ det amerikanske samfund hang sammen $i$ et kompliceret net af interrelationer. Pa samme made havde jo Karl Marx tidligere ved at iagttage og beskrive brydningerne $i$ det industrialiserede England fảet øje for sammenhængen mellem den okonomiske og den politiske udvikling.

Disse iagtagelser er $i$ dag dagligkost for alle vesteuropaere. Det er baggrunden for, at unge og yngre historikere fra England, USA, Frankrig og Tyskland, năr de skal redegore for deres syn på den historiske forskning, som det skete $i$ de næunte numre af Times Litterary Supplement, forbloffende samstemmende understreger, at historien har brug for at overtage og arbejde videre med sociologiske ideer, at man navnlig soger inspirationen i sociologi og andre samfundsvidenskaber, som de især er udviklet $i$ USA, og at man peger på den nærmeste fortids historie som et af de vigtigste studieomrader. Samtidshistorien er ved at blive det centrale studieobjekt for en voksende skare af historikere.

Men selv dyrkere af den klassiske historie kan man høre plædere for en sociologisk orienteret historie med udnyttelse af teknik og kategorier, udviklet $i$ de samfundsvidenskabelige nabodiscipliner.

Englænderen M. I. Finley, hvis område er antikkens sociale og okonomiske historie, udtrykker det pa den måde, at den klassiske historie bedst vil kunne retfærdiggore sin exsistens ved at koncentrere sine kræfter om de centrale menneskelige problemer, d.v.s. om vardier og sociale relationer, om politik og politisk adfærd, om so- 
ciale klasser og klassekonflikter, om de komplekse forbindelser mellem okonomi og politik.

\section{"Historiens nytte"}

Denne betragtning er central for forstaelsen af synspunkterne hos den historikertype, jeg her taler om. Det er historikere, som $i$ bevidst eller ubevidst fortsættelse af den franske historikerskole omkring "Annales" og under påvirkning fra samfundsvidenskaberne ser det som et mål i samarbejde med andre samfundsvidenskaber at skabe en omfattende videnskab om mennesket $i$ samfundet. Det er denne tendens, der rorer på sig rundt omkring.

Bl.a. er det iojnefaldende, at det i efterkrigsårene er blevet sværere og sværere for historikerne at opretholde en teori om, at deres arbejde ingen egentlig nytteværdi har. Kravene om en historieskrivning, der på andre præmisser end den hidtidige kolonihistorie vil skildre baggrunden for frigorelsesprocessen $i$ Asien og Afrika har ikke været til at komme uden om. Man har brug for at $f a$ skildret de nye stater og deres forudsætninger; Man vil have noget at vide om, hvordan det mellemostlige problem er blevet så brandende; man vil have besked om, hvorfor det danske landbrug er kommet $i$ en $i$ visse henseender umulig okonomisk situation, som truer med at blive permanent; man vil kende til de problemer, der kan være tale om $i$ forbindelse med de skandinaviske landes optagelse $i$ fællesmarkedet, og det vækker igen onsket om en beskrivelse af de kulturelle relationer mellem Skandinavien og kontinentet og en beskrivelse af kulturformidlingens mekanik.

Behovet for planlægning og indgreb $i$ samfundsudviklingen er blevet mere og mere accepteret $i$ vore lande. Men planlægningen kræver ikke blot viden om de mulige konsekvenser af indgrebene, men også om tilblivelsen og karakteren af de dele af samfundet, man vil andre på. Med alle disse og mange andre problemer vender man sig til historikerne. Og det interessante er, at flere g flere historikere giver sig til at besvare sporgsmalene. 
Men hermed kommer de til at betræde emneomrader, som også andre samfundsdiscipliner dyrker.

og dernast kommer historikerne $i$ konflikt med dybt indgroede forestillinger om deres fag og dets muligheder forestillinger, som har deres rod $i$ forrige arhundredes historisme og $i$ det opgor med positivismen på åndsvidenskabernes omrade, som jeg flere gange har hentydet til.

Det har varet og er stadig for mange historikere en trossatning, at den historiske forskning ikke kan producere resultater med en sa generel gyldighed, at de har prognosekarakter. Interessen for fortiden og studiet af den må hvile $i$ sig selv. Man kan kun studere fortiden for dens egen skyld, ikke fordi man derved opnar en viden, som kan være til nytte $i$ egentlig forstand. Højst vil man ga med til, at beskæftigelsen med så indviklede ting, som historikerne sysler med, kan træne intellektet. Det kan jo ogsa være ganske nyttigt men er ikke en fortjeneste ved historien alene.

\section{Historisk relativisme}

I fortsættelse af historismen har det været almindeligt meget stærkt at understrege relativiteten $i$ de historiske resultater og umuligheden $i$ at realisere blot et beskedent tillob til objektivitet i historien. Historieskrivningens resultater bliver, har man sagt, nåt ved introspektion og indfoling, ikke ved en rationel videnskabelig procedure.

Man har desuden lagt megen vægt på, at historien beskæftiger sig med det enkeltstånde, unikke tilfælde og beskriver det $i$ dets fulde individualitet, sa det a priori er givet, at det ikke kan ga ind $i$ mere generelle sammenhange og komparationer. Enkelttilfældet og ikke generaliseringer er efter denne opfattelse kernen $i$ historisk forskning.

Alle disse synspunkter, som jeg her har trængt utilladeligt sammen, tenderer jo mod, at historien ikke kan være "nyttig" eller "anvendelig" i sadvanlig forstand. 
ven kan ikke betragtes som en videnskab, der akkumulerer viden på samme måde som de såkaldte eksakte videnskaber. Men det er tydeligt, at flere og flere, navnlig yngre historikere, er blevet trætte af al denne unyttighed. Eller vi skal maske hellere sige, at de er trætte af at betragte sig selv som luksusforskere, der forsker for deres egen menneskelige udviklings og modnings skyld. De finder det ikke tilfredsstillende, at deres resultater $i$ bedste fald kun kan opbygge andre, og at de ikke yder et egentlig tilskud til vor viden om mennesket og dets problemer. Ubehaget bliver ikke mindre af, at de andre samfundsvidenskaber gennem dristige - vel ogsa ofte for dristige - teoridannelser og med nye teknikker søger frem mod de mal, historikerne ikke har vovet at sætte sig, siden det 19. arhundrede gjorde faget historie stort og velrenommeret, men samtidig fratog det ambitionerne.

Resultatet er, at man i dag kan se, at den vældige metodeinteresse, vi er vidne til, er dirigeret af to modsatte impulser. I den ene lejr finder man dem, der $i$ fortsattelse af de traditionelle synspunkter analyserer historiens metodeproblemer for at vise, at historien aldrig vil kunne honorere de krav, en ukyndig omverden stiller til den. De understreger, at historien beskæfiger sig med enkelttilfældet, og at dens objektivitets-og præcisionsniveau er stærkt begrænset. Videnskabelig historieskrivning er en chimære, siger den store engelske historiker, Isaiah Berlin, som er en meget skarpsindig fortaler for denne retning. Almindeligt sundt omdomme er nok til at forstå menneskelige væseners opforsel. Teoretisk skematisering forer $i$ hvert fald ikke til en sådan forståelse.

\section{Historie på samfundsvidenskabeligt grundlag}

Men der er andre, som går til de metodiske studier, drevet af en anden impuls. De anfægter vel ikke påstanden om, at i historieforskningen er interessen rettet mod den 'ndividualiserende forklaring med respekt for fænomenernes tids-og stedsbinding. Historikerne hænger $i$ tiden, som 
det er udtrykt. Men de onsker ikke at drage videre konklusioner af denne interesseorientering, end rimeligt er. De gennemdrofter de gamle historieteoretiske problemer for at afslore, hvor langt de gamle synspunkter kan bære.

Sigtet går her pa at befri debatten om historien som videnskab for de synspunkter, som uden dybere fundering har hæmmet en klar opfattelse af historiens muligheder som samfundsvidenskab. Fortegnet er positivt, hvor de ældre teoretikere brugte et negativt.

$0 \mathrm{~g}$ tilsyneladende er man nu ved at ga et skridt videre. Man sporer en stigende lyst hos mange historikere til ikke blot teoretisk at frigore sig fra - og dermed mener jeg: opnå at stå frit over for - de aldre opfattelser af historien, men ogsa at tage konsekvensen $i$ den praktiske forskning. Navnlig i den okonomiske historie ser man en tendens til nu at skrive historie med nær tilknytning til nationalokonomiens modeller og begrebsapparat. Endnu kendes denne okonometriske historieforskning mest $i$ det store udland, men enkelte skandinaviske eksempler findes dog fra de senere år.

Jeg skai ogsa ker nævne, at befolkningshistorien i Frankrig og England med stort talent $i$ efterkrigstiden er udviklet til et meget hojt stade ved sammensmeltning af historie og demografi. Deryed er fremkommet resultater, som er intet mindre end revolutionerende for vore hidtidige forestillinger om befolkningsbevægelser, fødselskontrol, opfattelsen af ægteskabet 0.s.v.

Det "unikke" og det "generelle"

Som afslutning pa disse betragtninger vil jeg prøve at vise mere konkret, hvordan denne sammenhæng mellem teoretisk befrielse og nye perspektiver $i$ forskningen kan tage sig ud. Jeg vil tage et af de snart gamle problemer $i$ den historieteoretiske debat, forholdet mellem det individuelle og det generelle $i$ historieforskningen, og se, hvad der sker med det, når det tages op pa ny. Netop pá dette felt har historikerne $i$ hoj grad 
været bundet af den problemstilling, der var aktuel ved århundredskiftet, da man søgte at definere et særligt grundlag for åndsvidenskaberne - navnlig historien. I den sammenhæng gjorde man jo meget ud af at fastsla skellet mellem de ideografiske, beskrivende videnskaber, hvortil historien horte, og de nomotetiske, lovskabende videnskaber, hvortil blandt mange andre de ovrige samfundsvidenskaber så må hore. I dem er det nemlig ganske almindeligt at se fremhevet, at deres mal er at "undersøge serier af ensartede hændelser for at kunne forudsige det, som vil hænde".

En sådan målsætning træffer man sjældent eller måske endog aldrig formuleret hos historikere, sa vi har her utvivlsomt fat $i$ et kritisk punkt i opgoret om historiens stilling mellem videnskaberne. For dem, der udmantede skellet mellem de ideografiske og de nomotetiske videnskaber var det et dogme, at der virkelig var tale om adskilte videnskabstyper med forskellige metoder. For dem var historien tilstrækkeligt karakteriseret ved at have et emneomrade, der bestod af fænomener med et særligt unikt træk. De historiske fænomener ved individualiteter, som ikke kunne klassificeres og behandles efter en almindelig videnskabelig metode.

Antagelig har dette synspunkt været så livskraftigt, fordi det $i$ udpræget grad underbygger en traditionelt given opdeling af disciplinerne. Det har gjort det tillokkende, at synspunktet ikke forstyrrede god ro og orden $i$ den akademiske republik. I hvert fald er den måde, man nu er tilbøjelig til at se problemet om det individuelle og det generelle pá, langt mindre folsom over for traditionsbestemte og administrativt givne faggrænser. Sa alene af den grund er det nye synspunkt ikke populært alle steder.

Det afgørende for de nyere teoretikere har været, at de ikke opfatter individualitet og generalitet som træk ved fanomenerne selv. De gä ud fra, at begrebsparret dækker to aspekter eller to beskrivelsesmuligheder, der står til vor radighed. Man kan vælge at understrege det, en række fænomener har fælles, eller man kan interessere sig for 
det, der giver fænomenerne individualitet, det, der adskiller dem fra de fænomener, de ellers kan klassificeres sammen med.

Det er udtrykt særdeles klart af amerikaneren Morris R. Cohen $i$ bogen Reason and Nature fra 1931. Der er mange andre, der har sagt noget lignende, men jeg refererer Cohen, fordi han er så klar. Han skriver, at det menneskelige intellekts anstrengelser kan ses som en spænding mellem to poler : Den ene vil yde retfærdighed til mangfoldigheden $i$ det konkrete tilfælde foran os, den anden vil gribe et underliggende abstrakt princip, som kontrollerer mere end det ene tilfælde foran os.

Măske kan jeg komme med et beskedent og sikkert ufuldkomment eksempel: Vil man beskrive besættelsen af Danmark den 9. april 1940, kan man orientere sig mod besættelsen som en type af besættelser. Man kan se den som et eksempel pa en stor krigsforende nabomagts invasion $i$ et lille, nedrustet, neutralt land, eller hvordan man nu vil formulere det.

Eller man kan interessere sig for det, der gav netop besættelsen af Danmark sit særpræg. Man skildrer da ikke en besættelse, men besættelsen - for nu at give det sprogligt udtryk.

Men vi må så holde fast ved, at dette skel ikke er absolut. Teoretikeren kan ikke operere med den danske besattelse som type $i$ sine teorisystemer, uden at han har en adækvat beskrivelse af besættelsen. Pa den anden side må også den beskrivelse, der går på det unikke aspekt ved fænomenerne, udnytte generelle teori-elementer. Selve begrebet "besættelse" er et saddant teori-element og uden eksistensen af det $i$ en teoretisk sammenhang, uden forestillingen om, hvad der mere generelt karakteriserer en besættelse, ville vi slet ikke være $i$ stand til at udskille og beskrive det særegne ved besættelsen af Danmark 1940.

Sammenhæng mellem det unikke og det generelle

Til syvende og sidst forudsætter altsa $i$ praksis 
de to sæt beskrivelser hinanden. Der er operationel sammenhæng mellem de to beskrivelsesmader og de intentioner, der ligger bag dem. Det mere end antydes af den amerikanske psykolog Gordon W. Allport. Han skriver i sin "Pattern and Growth in Personality" fra 1961, at behovet for at kombinere undersøgelsen af det almene med undersøgelsen af det unikke star ham mere og mere klart.

"Jo mere vi udforsker og opdager, hvad der er ensartet $i$ den menneskelige natur, des mere patrangende bliver det at tage hensyn til det individuelle (uniqueness er det ord, han bruger) i helhedens form og monster."

En opfattelse, der går i samme retning, finder man hos englænderen Frankel $i$ bogen "The Making of Foreign Policy". Han skriver, at både den historiske og den teoretiske måde at nærme sig tingene på er af vigtighed. Kun forbedret teori kan lede til bedre historiske monografier, der er bygget op efter ensartede principper, som gor sammenligning mulig. Kun sădanne monografier kan tjene som en sund basis for at kontrollere, forfine og forbedre teorierne. Det er nodvendigt at styre mellem den abstrakte skolastiks scylla og det Carybdis, som bestar i tor indsamling af fakta.

Det er formentlig en erfaring, man er ved at gore, eiler kommer til at gore mange steder. Konsekvensen af dette bliver så, at man ikke kan opstille et skarpt skel mellem videnskaber ud fra, om de søger frem til det individuelle eller det generelle ved fænomenerne. Man må i stedet tale om et skel mellem forskellige betragtningsmåder, som går tværs ned gennem de forskellige discipliner, enten man sá kalder dem historiske eller noget andet. Begge beskrivelsesmåder findes side om side $i$ alle samfunds discipliner, ja, oftest $i$ den samme undersøgelse.

Hvad jeg her har sagt betyder ikke, at historien kal opgive sin mission som den disciplin, der viser, hvordin det egentlig var - d.v.s. konfrontere vore mere eller mindre formaliserede forestillinger om omverdenen med, hvad 
kilderne siger herom. Men historien kan ikke blive ved med blot at foretage denne konfrontation pa sine egne mere eller mindre tilfældige præmisser. Den ma integreres $i$ den samlede samfundsvidenskabelige sammenhæng, hvor den givetvis har en selvstandig opgave.

\section{Arsag og virkning bag integrationstanken}

Nu kan man sa filosofere over, hvad der er arsag, og hvad der er virkning $i$ alt dette her. Om man begynder at gå på tværs, samtidig med at teoretikerne når frem til, at der er teoretisk dækning for det. Eller om det teoretiske ræsonnement blot er gennemfort for at legitimere onsket om, at der skal etableres det snæurest mulige samarbejde mellem historien og de ovrige samfundsvidenskaber. Under alle omstændigheder er det væsentligt, at disse teoretiske overvejelser og en stigende interesse for samfundsvidenskabelig integration optræder samtidigt $i$ nutidens historiske debat.

Den canadiske sociolog Charles Tilly har for ganske nylig udtrykt det på den måde, at historien og sociologien $i$ ojeblikket fra forskellige retninger bruser frem mod samme punkt med dampen oppe, regulatoren aben og med pibende flojter. Lad os hábe, fojer han til, at det vil vise sig, at de er pá forskellige spor, når de når frem.

Det er situationen $i$ en del af samfundsvidenskaben $i$ dag. Ideelt opfatter et stigende antal forskere deres situation $p \mathfrak{d}$ den måde, at de står over for en række udtryk for menneskets adfard $i$ en social sammenhæng $i$ fortid og nutid. Dem skal de udforske. Det vil sige, at de må stille en række sporgsmål. Sporgsmålene er det forste vigtige, og alle ma ud fra deres forskellige erfaringer hjælpe med at formulere dem relevant og adækvat.

Lige sa afgorende er det, at svarene bliver sa gode som muligt. Dertil må anvendes de metoder og den teknik, der er til radighed, uanset om den stammer fra den ene eller den anden disciplin. Kriteriet er alene om metoden er operationelt duelig. 
Interessant er det da, at et stigende antal historikere finder det frugtbart at anvende sociologiske og andre samfundsvidenskabelige begreber og teoridannelser $i$ deres arbejde, samtidig med at flere og flere sociologer vender sig mod historien. Enten tager de selv opgaver op $i$ aldre perioder, eller de soger i samarbejde med historikere at få det historiske perspektiv frem $i$ deres undersogelser af aktuelle tilstande.

\section{Samarbejde og specialisering}

Samarbejdet er på vej, stottet af den okonomiske udvikling, der har stillet ogede, omend ikke tilstrækkelige faciliteter til radighed for storre forskningsprojekter, team-work etc. Her har vi at gore med selvforstarkende tendenser, som spiller en rolle for dynamikken i den udvikling, jeg er i færd med at skitsere. Et samarbejde, som det, jeg antyder, kræver institutter og faciliteter, der kan give gode kontaktmuligheder for folk fra forskellige discipliner, der beskæftiger sig med samme emneområde. Bedre faciliteter giver mulighed for at lose storre opgaver. Men gennemførelsen af storre forskningsprojekter ved team-work forudsatter en fælles teoretisk ramme, en droftelse og justering af begrebsapparatet og folgelig storre muligheder for komparation og generalisation.

Også dette vil være med til at forstærke trangen hos historikere til at orientere sig mod samarbejde med discipliner, som søger at etablere teoretiske referencerammer for udforskningen af det menneskelige samfund. Endnu dyrkes vel den overvejende del af historisk forskning som enkeltmandsforskning. Det er primadonna-arbejde med detto fordele og ábenbare ulemper. Men etableringen af forskergrupper og projekter med mange medarbejdere er $i$ stadig udvikling. I takt hermed vil kravet om teoridannelse, et falles og vel etableret begrebsapparat etc. vokse. Meget $i$ øjeblikkets situation kan salledes tydes som tegn pa, at integrations-onskerne og integrations- 
mulighederne $i$ samfundsvidenskaberne vil oges og ogsa $i$ stigende grad fange historikerne ind. Man kan uden helt at forfalde til drommerier forestille sig en udvikling $i$ retning af en tilstand, hvor der ikke er tale om enten at drive politisk, okonomisk eller andre varianter af historie $i$ aflukkede departementer.

Man vil naturligvis nok have en hoj grad af specialisering - maske ogsa mere end $i$ ojeblikket - men det vil ikke hindre, at problemerne stilles op inden for rammerne af en sand "science humaine", en videnskab om mennesket i relation til dets samfundsskabte omgivelser. En videnskab, hvor de enkelte deldiscipliner virkelig finder deres berettigelse $i$ at være led $i$ den fælles anstrengelse pă at afdække så mange sider af relationen mellem menneske og omgivelser som muligt.

Ja, men heri er vel intet nyt, vil De måske sige. og det er der sådan set heller ikke. Jeg har jo ogsa peget pa,at der er forlobere nok for disse nye veje $i$ historien - Marx, den nye historie i Amerika $i$ dette århundredes forste tiår, kredsen om Annales.

Men alligevel er der noget nyt deri, at en række faktorer $\mathbf{i}$ øjeblikket synes at favorisere et gennembrud af denne holdning i historieforskningen. Voksende respekt for akademiske faggrænser, væksten i videnskabelige institutioners antal og storrelse, onsket om planlægning $i$ samfundet og kravet om viden som baggrund for denne planlægning, for blot at næune noget af det, jeg allerede har berort. Udviklingen af elektroniske og andre hjælpemidler, der giver hidtil ukendte muligheder for behandling af massedata. Alt dette trækker $i$ retning af en dybere og bredere udforskning af mennesket $i$ samfundet. Teoretisk og praktisk ruster mange historikere sig til at vare med uden at gore sig illusioner om de krav, det vil stille til dem.

\section{Forsvar for integrationen}

Det er klart, at troen på dette fremtidsperspek- 
ikke deles af alle historikere. I ojeblikket er det dem, der tror pa det, der forer det store ord, og det er dem, der bliver lagt mærke til. Men skeptikerne samler utvivlsomt kræfter til en reformulering af deres position og vil levere et forsvar for de gamle former for og synspunkter pa historisk forskning. At deres kritik vil kunne blive både besk og berettiget et stykke ad vejen, tor i hvert fald jeg ikke afvise.

Det er ogsa klart, at en linie, som den jeg her har trukket op, og som jeg gerne selv bekender mig til, kan føre både til skuffelse og til ufrugtbarhed. Bl.a. 10ber man den risiko, at man kapper forbindelsen over mellem det læsende publikum og den historiske forskning. Flere seriose forskere har allerede alvorligt tilradet, at historikerne holder op med at betjene sig af dagligsproget og soger frem mod et klart defineret specialsprog med en fagligt accepteret terminologi til at kommunikere forskningsresultaterne.

Så galt behøver det vel ikke at gå, men det er dog tydeligt, at der $i$ et tidsskrift som Annales undertiden trives en kunstig, konstrueret jargon efter recepten: Det gor ikke så meget, hvad du siger, blot du siger det anderledes.

Det kan heller ikke afvises, at afstanden til det læge publikum, hvis interesse jo $i$ høj grad har været den traditionelle histories raison d'être, vil blive storre, når og hvis historien går ind $i$ et jæunbyrdigt samarbejde med andre videnskaber, bruger deres formelt formulerede modeller, matematiserer sine problemstillinger, hvor det er muligt, tabulerer sine resultater o.s.v.

I det hele taget vil en kvantificerende tendens utvivisomt med stigende styrke gare sig gældende i historien - uden at det iovrigt vil ændre ved præmisserne for det hyppigt diskuterede objektivitetsproblem i historien. Pastande med tal behover jo ikke at være mindre subjektive end påstande formuleret på anden måde.

Centrale problemer vil derfor ikke løses, blot 
ved at man slär ind pa den vej, jeg har peget pa her. De vil andre udseende måske, men $i$ princippet vil de være de samme. Og nye vanskeligheder vil komme til. Det bliver ikke lettere at være historiker, det skal ingen tro. Nye færdigheder og ny indsigt vil være nodvendig, en strengere disciplin vil binde den enkelte forsker, og gøre det temmelig meget anderledes at være historiker.

Máske fejlbedommer vi de muligheder, vi forude skimter for en bred indsats for et dybtgående studium af mennesket. Maske er mulighederne virkelig til stede. Kun tiden kan give svaret. 